\title{
Effects of Dietary Intake and Supplementation of Indigenous Probiotic Lactobacillus Plantarum Dad-13 on Body Mass Index, Faecal Short-Chain Fatty Acid, and Gut Microbiota of Undernourished Children in East Lombok, Indonesia
}

Endang Rahayu ( $\sim$ endangsrahayu@ugm.ac.id )

Gadjah Mada University

Ahmad Mustangin

Gadjah Mada University

Suharman Suharman

Gadjah Mada University

llian Elvira

Gadjah Mada University

Mariyatun Mariyatun

Gadjah Mada University

Fathyah Hanum Pamungkaningtyas

Binus University

Pratama Nur Hasan

Gadjah Mada University

Tyas Utami

Gadjah Mada University

Muhammad Nur Cahyanto

Gadjah Mada University

Mohammad Juffrie

Gadjah Mada University

Research Article

Keywords: faecal microbiota, Lactobacillus plantarum, indigenous probiotic, undernourished children, Lombok Indonesia

Posted Date: February 16th, 2021

DOI: https://doi.org/10.21203/rs.3.rs-199053/v1 
License: (우 (i) This work is licensed under a Creative Commons Attribution 4.0 International License. Read Full License 


\section{Abstract}

Malnutrition has been a global public health problem, jeopardizing children growth and constituting a major cause of death in children in developing countries, including Indonesia. Malnourished person tends to have abnormal gut microbiota. Probiotics supplementation can be considered as one of preventative measures against imbalanced gut microbiota and pathogenic bacteria to enable optimum nutrition absorption. This study aimed to investigate the effects of dietary intake and supplementation of powder of indigenous probiotic Lactobacillus plantarum Dad-13 to undernourished children in East Lombok, Indonesia on their body mass index (BMI), faecal short-chain fatty acids and gut microbiota. This study was performed in a Randomized Double-Blind Placebo-Controlled design, involving 40 children aged 10-12 years old, with BMI/age ratio $\leq-2$ standard deviation (SD). Subjects were randomly divided into two groups namely placebo and probiotic group. The placebo group consumed 1 gram of skimmed milk daily while the probiotic group consumed $1 \mathrm{gram}$ of skimmed milk containing $1 \times 10^{9} \mathrm{CFU} /$ gram of $L$. plantarum Dad-13 daily, with consumption period of 60 days for both groups. The result showed that dietary intakes of both groups were below recommended value ( $<70 \%)$. Lactobacillus plantarum and Bifidobacterium significantly increased after probiotic consumption while Enterobacteriaceae and Klebsiella pneumonia significantly reduced. Short-chain fatty acid (acetate, propionate, butyrate) significantly increased in probiotic group, which consequently lowered pH level. Subsequently, a significant increase was observed in body weight and height in both groups at the end of the study. Only BMI of probiotic group increased after consumption of probiotics.

\section{Introduction}

Malnutrition is defined as deficiencies, excesses, or imbalances of energy and/ or nutrients (either macro- or micronutrients) intake of a person [1]. Insufficient intake of energy and/or nutrient of a person results in undernutrition, widely distinguished into stunting and wasting condition. A recent study confirmed that malnutrition is a global public health issue harming the lives and growth of children under five. In 2017, approximately $22.2 \%$ (151 million children under five globally) were being stunted and $7.5 \%$ (51 million children under five globally) were being wasted. Majority of undernutrition cases were observed in low- and middleincome countries, including Indonesia [2]. Malnutrition is often characterized by a person's body mass index (BMI). A study in 2013 revealed that the prevalence of malnutrition in Indonesia in children aged 5-12 years was $11.2 \%$, with $7.2 \%$ was classified as being thin and $4 \%$ was classified as being very thin. West Nusa Tenggara (NTB) was one of provinces having the highest prevalence of very thin children which was higher than average national level of $4 \%$ [3]. Although malnutrition does not directly cause death in children, it is associated with the cause of 54\% deaths among children in developing countries in 2001 [4].

Various studies have been conducted to investigate the relationship between consumption patterns and gut microbiota [5]. Dietary habit is a main factor affecting the diversity of gut microbiota by providing nutrients and conditioning intestinal microenvironment [6]. The changing composition of microbiota or dysbiosis can cause various diseases [7]. A "vicious cycle of undernutrition" was defined as inadequate dietary intake impaired immune response of a children resulting in enteric infections which later altered microbiota in their gut, dysregulated gut permeability and led to inflammation and malabsorption [8]. Furthermore, it was highlighted that the link of gut microbiota and undernutrition has made it possible for a therapeutic intervention to take place [8]. 
Probiotics supplementation can be considered as one of preventative measures against imbalanced gut microbiota and pathogenic bacteria. Probiotics are live organisms which, when consumed in sufficient amounts, confer beneficial effects on the host [9]. Probiotics supplementation can be considered as one of preventative measures against unbalanced gut microbiota and pathogenic bacteria, by either restoring host-microbe balance or preventing dysbiosis. Probiotic may increase the number of beneficial bacteria and decrease the less favourable ones, regulate colon environment, preserve body's immune system, and reduce the risk of colon cancer by lowering carcinogenic substances [10-12]. Probiotics are reported to have a greater effect on malnourished children compared to healthy children living in developing countries [13]. Other studies reported that consumption of probiotics Lactobacillus acidophilus, Lactobacillus casei CRL 431 and Lactobacillus reuteri DSM 17938 could increase the body weight of undernourished children [14,15].

Lactobacillus plantarum is one of the most common types of lactic acid bacteria found in traditional Indonesian fermented food [16,17]. Lactobacillus plantarum Dad-13 is a probiotic candidate isolated from dadih, fermented buffalo milk from West Sumatra, Indonesia. Past study reported that supplementation of fermented milk containing L. plantarum Dad-13 in 30 healthy Indonesian subjects showed a significant increase in the population of L. plantarum in faecal matters of all subjects and a decrease in the population of Enterobacteriaceae, E. coli and coliform non E. coli in the faecal matter of $>50 \%$ of the subjects [18]. Furthermore, a recent study reported that a safety assessment study of L. plantarum Dad-13 in Sprague Dawley rats showed that it survived gastrointestinal tracts, did not translocate in organs and blood of treated rats which indicated that L. plantarum Dad-13 is likely to be safe for human consumption [19].

Limited studies suggested that probiotics may have potential to improve children growth in developing countries and undernourished children [13]. This study aimed to investigate the effects of supplementation of $L$. plantarum Dad-13 in undernourished children in East Lombok, Indonesia. Additionally, dietary intake was also taken into account when analysis was performed on the effect of consuming L. plantarum Dad-13 on BMI, short chain fatty acid (SCFA) and pH in faecal samples, and population of Prevotella, Bacteroides fragilis, Clostridium coccoides, Bifidobacterium, Enterobacteriaceae, Escherichia coli, Klebsiella pneumonia, Enterococcus,

Streptococcus, and L. plantarum.

\section{Methods}

\section{Subjects}

In total, this study was conducted for 61 days, started with the first day to conduct screening phase and followed by sixty days of consumption phase. Forty primary school children aged 10-12 years old from East Lombok, Indonesia participated in this study. The participants were randomly and equally divided into two groups of 20 children, namely placebo group and probiotic group. All participants have met inclusion criteria, i.e. $\mathrm{BMI} \leq-2 \mathrm{SD}$, had no history of reaction to probiotics component. Candidates were excluded if they had a digestive system disorder and lactose intolerant. Subsequently, subjects would be disqualified from the study if during the study they took antibiotics, prebiotics, probiotics, supplements, or immune regulators. Before follow the research all subject must signed inform consent by the parent/legal guardian. During the study, subjects were obliged to fill in a subject diary to record their food intake, medical record and medicine intake, and defecation frequency. Subject who pass the criteria will given informed consent and must be signed accompanied by a parent or guardian who will accompany the subject during the research process. 


\section{Ethics Declaration}

The study protocol was approved by Medical and Health Research Ethics Committee (MHREC), Faculty of Medicine, Universitas Gadjah Mada (Approval reference: KE/0861/08/2018) Registered on 26 June 2018 and approved on 17 September 2018. This research done by regulation that applicable in Indonesia and based by guidelines from World Medical Assembly (Declaration Helsinki, last amendment, Edinburgh, Scotland, 2000 and last clarified in Tokyo, 2004, appendix 7) also with notes of CPMP on GCP (CPMP/ICH/135/95). Data information such as Informed Consent obtained from all participant/subject and signed from parent/legal guardian. This study also registered in Center For Research And Development Of Health Resources And Services, Health Research and Development Agency, Ministry of Health of the Republic of Indonesia with registration number INA-PA2HB87 (Registered on 16-12-2020).

\section{Research products}

Probiotic powder containing L. plantarum Dad-13 of $1 \times 10^{9} \mathrm{CFU} /$ gram were supplemented to probiotic group. The probiotic L. plantarum Dad-13 was deposited in ampoules at the Food and Nutrition Culture Collection (FNCC), Center for Food and Nutrition Studies, Universitas Gadjah Mada, Indonesia. Subsequently, probiotic powder was prepared using Halal media and stored in a refrigerator $\left(<4^{\circ} \mathrm{C}\right)$ before being consumed. Meanwhile, placebo group was given skim milk powder from commercial product.

\section{Research design}

This research was conducted using a Randomized Double-Blind Placebo-Controlled trial for 60 days. During the period of consumption, 1 gram of probiotic powder and 1 gram of skim milk powder were consumed by probiotic and placebo group, respectively. The subjects consumed the products during their school break time. Additionally, on Sunday or public holiday consumption was done at home. Figure 1 below depicts the research design in this study.

Figure 1. Schematic diagram of research design

\section{Faecal samples collection}

Faecal samples were collected twice, in the morning of day-1 and day-61. Each subject collected their faecal sample at home using a stool kit containing masks, gloves, trail paper, ice gel and sterile tubes, spoon, glass beads and RNA. Subjects were asked to defecate on a trail paper to avoid contamination by urine or other liquid. Two spoons of faecal specimen were quickly inserted into the tube. Subsequently, the faecal samples were transported to the laboratory in a cooler box $\left(<10^{\circ} \mathrm{C}\right)$ within a maximum of one hour after collection. Faecal samples were labelled and stored in a freezer at a temperature of $-25^{\circ} \mathrm{C}$ for further molecular analysis.

\section{Anthropometric measurement}

Measurement of weight and height of the subjects were performed every 30 days. A 2-m-long and 1-mm-wide metal tape (Microtoise) was used for height measurement, with round up to $0.1 \mathrm{~cm}$. Body weight was measured using an indoor light clothing and without shoes, with round up to $0.1 \mathrm{~kg}$. Each measurement was done twice for each subject and average value was used for data entry. 


\section{$\mathrm{pH}$ analysis for faecal samples and analysis of stool quality}

For each faecal sample, $0.2-1 \mathrm{~g}$ was taken and added with distilled water with ratio 1:5. The mixture was vortexed and $\mathrm{pH}$ was measured by inserting a glass electrode of $\mathrm{pH}$ meter [10]. Additionally, stool quality of each subject was evaluated in several parameters, i.e. consistency of feces, colour, frequency of defecation per day and number of days of defecation. Stool consistency was compared to Bristol Stool Chart consisted of type $1-7$ ( 1 being separate hard lump, to 7 being liquid consistency with no solid pieces). Colour of faeces consisted of type 1 - 4 ( 1 = yellow, 2= brownish yellow, 3= brown, 4= green) [20]. Frequency of defecation was counted per 10 days and number of days of defecation was counted per 10 days.

\section{Analysis of faecal microbiota with Real-Time PCR}

Gut microbiota of interest in this study are listed in Table 1 which are associated with malnutrition. Real-Time PCR was used to investigate the number of specific microbiota in a sample. Extraction of DNA used a ZymoBIOMICSTM DNA Miniprep Kit (D4300) from Zymo Research Corp. (USA). The extraction followed the instructions from the kit with a slight modification. DNA sample was contained in a column/well with a composition of $10 \mu \mathrm{L}$ Evagreen ${ }^{\circledR}, 1 \mu \mathrm{L}$ forward primer, $1 \mu \mathrm{L}$ reverse primer, and $1 \mu \mathrm{L}$ isolated DNA. Doubledistilled water $\left(\mathrm{ddH}_{2} \mathrm{O}\right)$ was added until the solution reached $20 \mu \mathrm{L}$. In the process of amplification in PCR, each had its specific condition (Table 1), especially for annealing temperature for each primer. The selected microbiota was analysed in a selected DNA sample using a primer.

Table 1. List of primers and PCR condition 


\begin{tabular}{|c|c|c|c|c|}
\hline No & Bacteria & Primer & Conditions & Source \\
\hline 1 & Prevotella & $\begin{array}{l}\text { forward (g-Prevo-F) } \\
\text { CACRGTAAACGATGGATGCC, } \\
\text { reverse (g-Prevo-R) } \\
\text { GGTCGGGTTGCAGACC. }\end{array}$ & $\begin{array}{l}1 \text { cycle at } 98^{\circ} \mathrm{C} \text { for } 2 \mathrm{~min} \text {, } \\
34 \text { cycles at } 98^{\circ} \mathrm{C} \text { for } 2 \mathrm{sec} \\
\text { and } 57.1^{\circ} \mathrm{C} \text { for } 30 \mathrm{sec} \text {, } \\
\text { the last } 1 \text { cycle at } 65^{\circ} \mathrm{C}- \\
95^{\circ} \mathrm{C} \text { for } 5 \mathrm{sec} \text {. }\end{array}$ & [33] \\
\hline 2 & $\begin{array}{l}\text { Bacteroides } \\
\text { fragilis }\end{array}$ & $\begin{array}{l}\text { forward (g-Bfra-F2) } \\
\text { AYAGCCTTTCGAAAGRAGAT, } \\
\text { reverse (g-Bfra-R) CCAGTATCAACT } \\
\text { GCAATTTTA. }\end{array}$ & $\begin{array}{l}1 \text { cycle at } 98^{\circ} \mathrm{C} \text { for } 2 \mathrm{~min} \text {, } \\
34 \text { cycles at } 98^{\circ} \mathrm{C} \text { for } 2 \mathrm{sec} \\
\text { and } 50^{\circ} \mathrm{C} \text { for } 30 \mathrm{sec} \text {, } \\
\text { at last } 1 \text { cycle at } 65^{\circ} \mathrm{C}- \\
95^{\circ} \mathrm{C} \text { for } 5 \text { sec. }\end{array}$ & [33] \\
\hline 3 & $\begin{array}{l}\text { Clostridium } \\
\text { coccoides }\end{array}$ & $\begin{array}{l}\text { forward (g-Ccoc-F) } \\
\text { AAATGACGG TACCTGACTAA, reverse } \\
\text { (g-CCOC-R) } \\
\text { CTTTGAGTTTCATTCTTGCGAA. }\end{array}$ & $\begin{array}{l}1 \text { cycle at } 98^{\circ} \mathrm{C} \text { for } 2 \mathrm{~min} ; 34 \\
\text { cycles at } 98^{\circ} \mathrm{C} \text { for } 2 \mathrm{sec} \text { and } \\
52^{\circ} \mathrm{C} \text { for } 30 \mathrm{sec} \\
\text { at last } 1 \text { cycle at } 65^{\circ} \mathrm{C}- \\
95^{\circ} \mathrm{C} \text { for } 5 \text { sec. }\end{array}$ & [33] \\
\hline 4 & Bifidobacterium & $\begin{array}{l}\text { g-Bifid-F (CTCCTGGAAACGGGTGG) } \\
\text { Bifid-R } \\
\text { (GGTGTTCTTCCCGATATCTACA }\end{array}$ & $\begin{array}{l}1 \text { cycle at } 98^{\circ} \mathrm{C} \text { for } 2 \mathrm{~min} \text {; } \\
34 \text { cycles at } 98^{\circ} \mathrm{C} \text { for } 2 \mathrm{sec} \\
\text { and } 58.8^{\circ} \mathrm{C} \text { for } 30 \mathrm{sec} \text {. At } \\
\text { last } 1 \text { cycle at } 65^{\circ} \mathrm{C}-95^{\circ} \mathrm{C} \\
\text { for } 5 \text { sec. }\end{array}$ & [33] \\
\hline 5 & Enterobacteriaceae & $\begin{array}{l}\text { En-Isu-3F } \\
\text { (TGCCGTAACTTCGGGAGAAGGCA) } \\
\text { and En-Isu-3R } \\
\text { (TCAAGGACCAGTGTTCAGTGTC) for }\end{array}$ & $\begin{array}{l}1 \text { cycle at } 98^{\circ} \mathrm{C} \text { for } 2 \mathrm{~min} ; \\
34 \text { cycles at } 98^{\circ} \mathrm{C} \text { for } 2 \mathrm{sec} \\
\text { and } 60^{\circ} \mathrm{C} \text { for } 30 \text { sec. At last } \\
1 \text { cycle at } 65^{\circ} \mathrm{C}-95^{\circ} \mathrm{C} \text { for } 5 \\
\text { sec. }\end{array}$ & [33] \\
\hline 6 & Escherichia coli & $\begin{array}{l}\text { forward (g-Ecoli-F) } \\
\text { CATGCCGCGTGTATGAAGAA reverse } \\
\text { (Ecoli-R) } \\
\text { CGGGTAACGTCAATGAGCAAA }\end{array}$ & $\begin{array}{l}1 \text { cycle at } 98^{\circ} \mathrm{C} \text { for } 2 \mathrm{~min} \text {; } \\
\text { then } 34 \text { cycles at } 98^{\circ} \mathrm{C} \text { for } 2 \\
\text { sec and } 59.9^{\circ} \mathrm{C} \text { for } 30 \text { sec, } \\
\text { with the last } 1 \text { cycle at } \\
65^{\circ} \mathrm{C}-95^{\circ} \mathrm{C} \text { for } 5 \text { sec. }\end{array}$ & [34] \\
\hline 7 & $\begin{array}{l}\text { Klebsiella } \\
\text { pneumoniae }\end{array}$ & $\begin{array}{l}\text { forward (Kpneu-F) } \\
\text { CCTGGATCTGACCCTGCAGTA } \\
\text { reverse (Kpneu-R) } \\
\text { CCGTCGCCGTTCTGTTTC }\end{array}$ & $\begin{array}{l}1 \text { cycle at } 98^{\circ} \mathrm{C} \text { for } 2 \mathrm{~min} ; \\
\text { then } 34 \text { cycles at } 98^{\circ} \mathrm{C} \text { for } 2 \\
\text { sec and } 61^{\circ} \mathrm{C} \text { for } 30 \mathrm{sec} \text {, } \\
\text { with the last } 1 \mathrm{cycle} \text { at } \\
65^{\circ} \mathrm{C}-95^{\circ} \mathrm{C} \text { for } 5 \text { sec. }\end{array}$ & [35] \\
\hline 8 & Streptococcus & $\begin{array}{l}\text { forward } \\
\text { CTWACCAGAAAGGGACGGCT } \\
\text { reverse AAGGRYCYAACACCTAGC }\end{array}$ & $\begin{array}{l}1 \text { cycle at } 98^{\circ} \mathrm{C} \text { for } 2 \text { min } \\
\text { then } 34 \text { cycles at } 98^{\circ} \mathrm{C} \text { for } 2 \\
\text { seconds and } 58^{\circ} \mathrm{C} \text { for } 30 \\
\text { seconds and with the last } 1 \\
\text { cycle at } 65^{\circ} \mathrm{C}-95^{\circ} \mathrm{C} \text { for } 5 \\
\text { seconds }\end{array}$ & [36] \\
\hline
\end{tabular}




\begin{tabular}{|c|c|c|c|c|}
\hline No & Bacteria & Primer & Conditions & Source \\
\hline 9 & Enterococcus & $\begin{array}{l}\text { forward (g-Encoc-F) } \\
\text { ATCAGAGGGGGATAACACTT } \\
\text { reverse (g-Encoc-R) } \\
\text { ACTCTCATCCTTGTTCTTCTC. }\end{array}$ & $\begin{array}{l}\text { The amplification cycle for } \\
\text { Enterococcus primer was } 1 \\
\text { cycle at } 98^{\circ} \mathrm{C} \text { for } 2 \text { minutes } \\
\text { then } 34 \text { cycles at } 98^{\circ} \mathrm{C} \text { for } 2 \\
\text { seconds and } 48^{\circ} \mathrm{C} \text { for } 30 \\
\text { seconds and the last } 1 \\
\text { cycle at } 65^{\circ} \mathrm{C}-95^{\circ} \mathrm{C} \text { for } 5 \\
\text { seconds. }\end{array}$ & [33] \\
\hline 10 & $\begin{array}{l}\text { Lactobacillus } \\
\text { plantarum } \\
\text { subgroup }\end{array}$ & $\begin{array}{l}\text { sg-Lpla-F } \\
\text { (CTCTGGTATTGATTGGTGCTTGCAT) } \\
\text { and sg-Lpla-R } \\
\text { (GTTCGCCACTCACTCAAATGTAAA) } \\
\text { for }\end{array}$ & $\begin{array}{l}1 \text { cycle at } 98^{\circ} \mathrm{C} \text { for } 2 \text { min; } \\
34 \text { cycles at } 98^{\circ} \mathrm{C} \text { for } 2 \mathrm{sec} \\
\text { and } 60^{\circ} \mathrm{C} \text { for } 30 \text { sec. At last } \\
1 \text { cycle at } 65^{\circ} \mathrm{C}-95^{\circ} \mathrm{C} \text { for } 5 \\
\text { sec. }\end{array}$ & [33] \\
\hline
\end{tabular}

\section{Analysis of Short-chain fatty acid}

Analysis of short chain fatty acid (SCFA) followed the methods by [21]. Approximately $0.5-1 \mathrm{gram}$ of fecal sample was added with distilled water with ratio of 1:3. Subsequently, the mixture was vortexed for 5 minutes, followed by centrifugation at $10000 \mathrm{rpm}$ for 10 minutes. The supernatant was then analysed using gas chromatography (GC) (Shidmadzu, GC 2010 plus series) with specifications of $240^{\circ} \mathrm{C}$ injector, RTX-Wax column, column length $30 \mathrm{~m}$, column temperature $145^{\circ} \mathrm{C}$, diameter 0.25 , column flow 0.8 minutes with helium as carrier gas and flame ionization detector (FID) at $240^{\circ} \mathrm{C}$.

\section{Statistical analysis}

Statistical analysis was performed using IBM Statistic SPSS 20.0 with $95 \%$ confidence interval $(a=5 \%)$. ChiSquare Test; independent t-test; Wilcoxon test were carried out to evaluate the significant differences of observed parameters between placebo and probiotic-treated group. In addition, a paired t-test was used to analyse the observed parameters before and after consumption of placebo powder or indigenous probiotic powder.

\section{Results}

\section{Demographic and anthropometric data of subjects}

Table 2 below shows demographic and anthropometric data of the subjects. In both placebo and probiotic groups, subjects have similar characteristics in gender, age, body weight and height, and BMI as proven by statistical tests ( $p>0.05$, confidence level $95 \%$ ). Both sexes (female and male) were equally represented in both groups. Subjects in both groups had average age of 11 years old with BMI in placebo group and probiotic group were $14.64 \mathrm{~kg} / \mathrm{m}^{2}$ and $14.09 \mathrm{~kg} / \mathrm{m}^{2}$, respectively.

Table 2. Demographic and anthropometric data 


\begin{tabular}{|c|c|c|c|}
\hline Characteristics & Placebo Group & Probiotic Group & $p$-value \\
\hline Male, n (\%) & $12(60 \%)$ & $10(50 \%)$ & \multirow[t]{2}{*}{0.75} \\
\hline Female, n (\%) & $8(40 \%)$ & $10(50 \%)$ & \\
\hline Age, (years, months) & $11.11 \pm 0.69$ & $11.16 \pm 0.67$ & 0.84 \\
\hline Weight, (kg) & $25.75 \pm 4.32$ & $25.35 \pm 3.08$ & 0.74 \\
\hline Height (cm) & $100,32 \pm 8,18$ & $100,34 \pm 5,14$ & 0.40 \\
\hline $\mathrm{BMI},\left(\mathrm{kg} / \mathrm{m}^{2}\right)$ & $14.64 \pm 1.12$ & $14.09 \pm 1.31$ & 0.16 \\
\hline \multicolumn{4}{|c|}{ Data are presented as mean \pm standard deviation. } \\
\hline \multicolumn{4}{|c|}{$\begin{array}{l}\text { p-value was analysed using Pearson chi-square test (for gender) and independent T-test (for age, weight and } \\
\text { BMI). }\end{array}$} \\
\hline
\end{tabular}

The effect of consumption of indigenous probiotic L. plantarum Dad-13 powder on the body weight, height, and $\mathrm{BMI}$ of under nutrition school age children is shown in Table 3. In placebo group, a significant increase on the body weight and height was observed after consumption of placebo (skim milk) powder for 30 days. The increase on the body weight and height continued up to 60 days of consumption of placebo powder. However, there was no substantial change of BMI of children who consumed placebo products. On the other hand, in probiotic group, the body weight, height, and BMI significantly increased after consuming probiotic powder for 30 days, and further increased after another 30 days of consumption. The BMI increased about $0.89 \mathrm{~kg} / \mathrm{m}^{2}$ after 60 days consumption of $L$. plantarum Dad-13 powder. Higher increase in body weight and BMI of probiotic group might be linked to the colonization of $L$. plantarum Dad-13, which might have helped maintain the integrity of the intestine, thereby facilitate a more optimum nutrient absorption.

Table 3. Effect of consumption of powder of probiotic L. plantarum Dad-13 on weight, height, and BMI of under nutrition school age children in Lombok

\begin{tabular}{|c|c|c|c|c|c|c|}
\hline & \multicolumn{3}{|l|}{ Placebo } & \multicolumn{3}{|l|}{ Probiotic } \\
\hline & Day-0 & Day-30 & Day-60 & Day-0 & Day-30 & Day-60 \\
\hline \multirow{2}{*}{$\begin{array}{l}\text { Weight } \\
(\mathrm{kg})\end{array}$} & \multirow[t]{2}{*}{$25.75 \pm 4.31$} & $26.15 \pm 4.07 *$ & $26.76 \pm 4.18^{\star}$ & \multirow[t]{2}{*}{$25.35 \pm 3.08$} & $26.78 \pm 3.33^{\star}$ & $27.67 \pm 3.01^{\star}$ \\
\hline & & $(0.042)$ & $(0.001)$ & & $(0.001)$ & $(0.001)$ \\
\hline \multirow{2}{*}{$\begin{array}{l}\text { Height } \\
\text { (cm) }\end{array}$} & \multirow[t]{2}{*}{$132.16 \pm 8.19$} & $133.61 \pm 7.85^{\star}$ & $134.36 \pm 7.78^{\star}$ & \multirow[t]{2}{*}{$134.02 \pm 5.14$} & $134.79 \pm 5.31$ * & $135.87 \pm 5.24$ * \\
\hline & & $(0.000)$ & $(0.000)$ & & $(0.001)$ & $(0.001)$ \\
\hline \multirow{2}{*}{$\begin{array}{l}\text { BMI } \\
\left(\mathrm{kg} / \mathrm{m}^{2}\right)\end{array}$} & \multirow[t]{2}{*}{$14.64 \pm 1.11$} & $14.57 \pm 0.94$ & $14.73 \pm 0.89$ & \multirow[t]{2}{*}{$14.09 \pm 1.31$} & $14.71 \pm 1.30^{\star}$ & $14.98 \pm 1.30$ * \\
\hline & & $(0.573)$ & $(0.560)$ & & $(0.001)$ & $(0.001)$ \\
\hline
\end{tabular}

\section{Dietary pattern}


Food types, food composition and energy levels of each food ingredient were analysed using NutriSurvey software. Table 4 shows that the average energy intakes in both groups were less than $70 \%$ of the recommended dietary allowance (RDA) providing that it was an indication of undernourished children as defined by the Nutritional Adequacy Figures [3]. Macro- and micronutrients intake in the subjects also did not meet the standard of RDA in both groups, with carbohydrate and protein were the most highly consumed, while dietary fibers, iron, and vitamins were the least consumed. The energy, macro- and micronutrients intake between the placebo and the probiotic groups were not significantly different. Typical foods which were mostly consumed by the study subjects are provided in Table 5 . It can be seen that the sources of carbohydrate were mainly rice and noodle, while the sources of protein were mainly from the consumption of fish and seafoods. Children with inadequate intake of energy, protein, fat and carbohydrate have a greater risk of malnutrition than those who have adequate energy, protein, fat and carbohydrate intake. Malnutrition, especially stunting and wasting, are caused by poor dietary habits and less consumption of fruits and vegetables [22].

Table 4. The average nutrient intake of undernourished children in East Lombok for 60 days of treatment period

\begin{tabular}{|c|c|c|c|c|c|c|}
\hline \multirow[t]{2}{*}{ Nutrient Intake } & \multirow[t]{2}{*}{$\left.\mathrm{RDA}^{\star}\right)$} & \multicolumn{4}{|l|}{ Average Intake \pm SD } & \multirow[t]{2}{*}{$p$-value } \\
\hline & & Placebo $(n=20)$ & $\%$ RDA & Probiotic $(n=20)$ & $\%$ RDA & \\
\hline Energy (kcal) & 2036.30 & $1213.46 \pm 230.26$ & 59.59 & $1105.83 \pm 142.73$ & 54.30 & 0.31 \\
\hline Protein (g) & 60.10 & $47.65 \pm 7.95$ & 79.28 & $39.60 \pm 3.99$ & 65.89 & 0.07 \\
\hline Fat (g) & 69.10 & $32.76 \pm 3.57$ & 47.41 & $26.51 \pm 3.96$ & 38.36 & 0.06 \\
\hline Carbohydrate (g) & 290.70 & $178.68 \pm 45.58$ & 61.47 & $174.76 \pm 26.61$ & 60.12 & 0.85 \\
\hline Dietary Fiber (g) & 28.00 & $6.71 \pm 2.54$ & 23.96 & $6.53 \pm 1.59$ & 23.32 & 0.88 \\
\hline Calcium (mg) & 1100.00 & $1213.46 \pm 230.26$ & 59.59 & $1105.83 \pm 142.73$ & 54.30 & 0.31 \\
\hline Magnesium (mg) & 250.00 & $220.41 \pm 29.60$ & 88.16 & $228.68 \pm 23.25$ & 91.47 & 0.61 \\
\hline Iron (mg) & 15.00 & $5.43 \pm 0.85$ & 36.20 & $4.45 \pm 0.36$ & 26.73 & 0.80 \\
\hline Zinc (mg) & 7.00 & $4.75 \pm 0.73$ & 67.86 & $4.00 \pm 0.36$ & 57.14 & 0.06 \\
\hline Vit. E (mg) & 11.00 & $3.10 \pm 0.83$ & 28.18 & $3.10 \pm 0.73$ & 28.18 & 1.00 \\
\hline Vit. A $(\mu \mathrm{g})$ & 900.00 & $367.05 \pm 76.49$ & 40.78 & $424.30 \pm 25.13$ & 47.14 & 0.06 \\
\hline Vit. B1 (mg) & 1.00 & $0.38 \pm 0.07$ & 38.00 & $0.35 \pm 0.08$ & 35.00 & 0.17 \\
\hline Vit. B2 (mg) & 1.20 & $0.51 \pm 0.04$ & 42.50 & $0.48 \pm 0.07$ & 40.00 & 0.17 \\
\hline
\end{tabular}

*) Recommended Dietary Allowances (RDA);

$p$-value was calculated based on t-test and Wilcoxon test

Table 5. Typical foods consumed by study participants and its contribution to the nutrient intake 


\begin{tabular}{|c|c|c|c|}
\hline \multirow[t]{2}{*}{ Food Item } & \multicolumn{2}{|c|}{ Average intake $(\%) \pm S D$} & \multirow[t]{2}{*}{$p$-value } \\
\hline & Placebo & Probiotic & \\
\hline \multicolumn{4}{|c|}{ Protein-based foods } \\
\hline Fish and Seafood & $34.20 \pm 4.01$ & $30.28 \pm 2.01$ & 0.32 \\
\hline Meat & $22.20 \pm 2.01$ & $19.26 \pm 2.99$ & $0.03^{*}$ \\
\hline Egg & $12.20 \pm 1.99$ & $7.59 \pm 1.95$ & 0.06 \\
\hline Legume & $7.40 \pm 1.04$ & $6.12 \pm 2.01$ & 0.32 \\
\hline Others & $3.28 \pm 2.01$ & $2.46 \pm 0.98$ & 0.49 \\
\hline \multicolumn{4}{|c|}{ Carbohydrate-based foods } \\
\hline Rice and porridge & $32.96 \pm 1.99$ & $34.05 \pm 2.99$ & 0.20 \\
\hline Noodle & $13.89 \pm 3.60$ & $9.67 \pm 1.99$ & $0.05^{\star}$ \\
\hline Bread and Cereal & $8.58 \pm 2.01$ & $9.44 \pm 1.98$ & 0.74 \\
\hline Others & $5.98 \pm 0.99$ & $6.96 \pm 2.64$ & 0.43 \\
\hline \multicolumn{4}{|c|}{ Dietary fiber-based foods } \\
\hline Fruit & $9.72 \pm 2.02$ & $10.26 \pm 1.99$ & 0.86 \\
\hline Vegetable & $8.94 \pm 1.99$ & $8.54 \pm 2.03$ & 0.083 \\
\hline Others & $5.30 \pm 2.05$ & $4.54 \pm 0.98$ & 0.53 \\
\hline \multicolumn{4}{|c|}{$\begin{array}{l}\text { The average intake (\%) was calculated from the average nutrient intake divided by the RDA of nutrient ) } \\
100 \%\end{array}$} \\
\hline${ }^{*} p<0.05$ significan & $n$ placebo an & sed on t-test a & est \\
\hline
\end{tabular}

\section{Faecal microbiota in subjects}

Consumption of L. plantarum Dad-13 in undernourished children might influence some bacterial population in the gut. Figure 2 shows that population of L. plantarum and Bifidobacterium increased significantly.

Pathogenic bacteria, Enterobacteriaceae and Klebsiella decreased significantly after consumption of probiotics. The figure also shows the changes of population of strictly anaerobic bacteria i.e. C. coccoides, B. fragilis, Prevotella, and in both groups, before and after the supplementation of probiotic product. Among those three bacteria, only population of $C$. coccoides decreased significantly while the population of the other two bacteria did not change much.

From this result also showed that Prevotella is more dominant than Bacteroides and Clostridium. It could be concluded that Indonesian undernourished children have the Prevotella enterotype, which is supported by their diet like other children in Indonesia. This also in line with previous study. A regional study in Asia reported that microbiota of primary school children in five Asian countries were influenced by their different eating habits. Gut microbiota of children in Yogyakarta and Bali (Indonesia) and Khon Kaen (Thailand) were dominated by 
Prevotella group, linked to the high amount of rice consumption. Meanwhile, children in China, Japan, and Taiwan harbored abundant population of Bifidobacterium and Bacteriodes group [23].

The asterisk sign (*) shows a significant difference of microbiota before and after consumption of probiotic powder based on paired t-test

\section{Short chain fatty acid in subjects}

Some studies suggested that probiotics may affect production of short chain fatty acid (SCFA) in gastrointestinal tract. Table 6 shows profile of SCFA before and after consumption period in group of placebo and probiotic. Acetate, propionate, and butyrate level in probiotic groups significantly increased after consumption of probiotic, while the increase in placebo group was not significant. Propionate increased more than two folds of initial condition, from 6,7 to $14,54 \mathrm{mmol} / \mathrm{g}$ feces. These findings are similar to previous studies where consumption of fermented milk containing L. casei Shirota strain $3 \times 10^{10} \mathrm{CFU} / \mathrm{ml}$ and galactooligosaccharide $2.5 \mathrm{~g} / 80 \mathrm{~mL}$ for 2 weeks significantly increased acetic acid [10]. Additionally, consumption of L. plantarum P-8 for 5 weeks were able to significantly increase acetic acid, propionic acid, butyric acid. Acetic acid and lactic acid can reduce $\mathrm{pH}$ of intestinal environment which made it unfavourable for the colonialization of pathogens. Meanwhile, butyric acid is able to induce catalydine, an antimicrobial peptide in the intestine [24].

Table 6. Profile of SCFA (mmol / $\mathrm{g}$ feces) in placebo and probiotic group before and after consumption period $($ mean \pm SD)

\begin{tabular}{|c|c|c|c|c|c|c|}
\hline & Placebo & & & Probiotic & & \\
\hline SCFA & Before & After & $p$-Value & Before & After & $p$-value \\
\hline Acetate & $26.59 \pm 22.16$ & $35.55 \pm 20.62$ & 1.94 & $24.45 \pm 16.81$ & $37.24 \pm 16.67$ & $0.021^{*}$ \\
\hline Propionate & $8.51 \pm 7.75$ & $11.83 \pm 7.79$ & 1.84 & $6.70 \pm 4.83$ & $14.54 \pm 10.84$ & $0.005^{\star}$ \\
\hline Butyrate & $3.75 \pm 2.76$ & $4.87 \pm 3.26$ & 2.50 & $4.16 \pm 2.82$ & $6.94 \pm 4.51$ & $0.025^{\star}$ \\
\hline
\end{tabular}

\section{pH analysis and stool quality}

Table 7 shows an overview of $\mathrm{pH}$ and stool quality in both groups. No significant changes were observed in $\mathrm{pH}$ and all parameters of stool quality in placebo group. Stool consistency in probiotic group also were improved after consumption from type 2 and type 3 to type 4 . Type 4 is considered as a normal stool consistency.

$\mathrm{pH}$ in probiotic group significantly decrease after consumption of probiotic L. plantarum Dad-13 from 6.57 to 6.15. Lower $\mathrm{pH}$ was associated to the decrease of Enterobacteriaceae population. A previous study reported that a decrease in faecal $\mathrm{pH}$ value in subjects consuming fermented milk containing synbiotic of Lactobacillus casei Shirota strain and galactooligosaccharide for 1 and 2 weeks was attributable to the large production of intestinal organic acids by bacteria (butyric acid, propionic acid, and lactic acid) which later stimulated motility in colon [10]. Accordingly, decrease in faecal pH is affected by the number and activity of microorganisms in the 
colon producing abovementioned acids and other bacteria which reduce the population of pathogenic bacteria such as Enterobacteriaceae.

Table 7. $\mathrm{pH}$ Value and stool quality

\begin{tabular}{|c|c|c|c|c|c|c|}
\hline \multirow[t]{2}{*}{ Item } & \multicolumn{3}{|c|}{ Placebo $(n=20)$} & \multicolumn{3}{|c|}{ Treatment $(n=20)$} \\
\hline & $\begin{array}{l}\text { Before } \\
\text { Consumption } \\
\text { mean } \pm \text { SD }\end{array}$ & $\begin{array}{l}\text { After } \\
\text { Consumption } \\
\text { mean } \pm \text { SD }\end{array}$ & $p$-value & $\begin{array}{l}\text { Before } \\
\text { Consumption } \\
\text { mean } \pm \text { SD }\end{array}$ & $\begin{array}{l}\text { After } \\
\text { Consumption } \\
\text { mean } \pm \text { SD }\end{array}$ & $p$-value \\
\hline $\mathrm{pH}$ & $6.42 \pm 0.46$ & $6.43 \pm 0.62$ & 0.17 & $6.57 \pm 0.54$ & $6.15 \pm 0.57$ & $0.007 *$ \\
\hline $\begin{array}{l}\text { Consistency (1- } \\
\text { 7) }\end{array}$ & $3.45 \pm 1.35$ & $3.50 \pm 0.67$ & 0.88 & $2.65 \pm 0.67$ & $4.00 \pm 0.27$ & $0.00 *$ \\
\hline Colour (1-4) & $2.95 \pm 0.88$ & $2.99 \pm 0: 58$ & 0.1 & $2.75 \pm 0.74$ & $2.97 \pm 0.60$ & 0.13 \\
\hline $\begin{array}{l}\text { Frequency of } \\
\text { defecated } \\
\text { (number/10d) }\end{array}$ & $7.20 \pm 0.41$ & $7.28 \pm 0.53$ & 0.55 & $7.35 \pm 0.48$ & $7.54 \pm 0.38$ & 0.17 \\
\hline $\begin{array}{l}\text { Day of defecated } \\
\text { (d/10d) }\end{array}$ & $7.10 \pm 0.30$ & $7.19 \pm 0.25$ & 0.37 & $7.05 \pm 0.60$ & $7.28 \pm 0: 53$ & 0.2 \\
\hline \multicolumn{7}{|c|}{$\begin{array}{l}\text { Consistency of feces (type 1: separate hard lumps; } 2 \text { : lumpy and sausage like; } 3 \text { : a sausage with cracks in } \\
\text { the surface; 4: like a smooth, soft sausage or snake; } 5: \text { soft blobs with clear-cut edges; } 6 \text { : mushy consistency } \\
\text { with ragged edges; 7: liquid consistency with no solid pieces). Colour of feces (1: yellow; } 2 \text { : brownish yellow; } \\
\text { 3: brown; 4: green). }\end{array}$} \\
\hline
\end{tabular}

\section{Discussion}

It was reported an existence of relationship between the condition of gut microbiota and incidence of malnutrition [4]. Malnourished person tends to have abnormal gut microbiota (dysbiosis) and increased population of aerotolerant pathogenic bacteria such as Enterobacteriaceae and Streptococcus. Subsequently, the growth of anaerobic microbiota will be delayed and inhibited, resulted in reduced maturation of Bifidobacteria and Lactobacillus. Gut microbiota maturation occurs mainly during the first three years of life course and is associated with increased diversity of human gut microbiota, especially Firmicutes and Bacteroidetes. In a cross-sectional study in Bangladesh, malnourished children was associated with less diverse microbiota characterized by lower Bacteriodetes (18\% compared to $44 \%$ from healthy subjects), higher Proteobacteria (46\% compared to 5\% from healthy subjects), and higher pathogenic bacteria such as Klebsiella and Escherichia, which were 174 and 9-fold higher than the healthy subjects [25]. A study in 2017 reported from the analyzed stool sample of malnourished patients with kwashiorkor and healthy children collected from Nigeria and Senegal, it showed an increase of potentially pathogenic Proteobacteria, Furobacteria, Streptococcus gallotycus [26].

Undernourished microbiota linked with the gut microbiota, immaturity, altered diversity, enrichment in potentially pathogenic and inflammagenic species, depletion in obligate anaerobe and less efficient nutrient utilization [27]. 
The gut microbiota modulated by probiotics have the ability to fight against pathogenic bacteria by exploiting host' nutrients [28]. Subsequently, probiotics increase short-chain fatty acid (SCFA) in the bacterial colonies to reduce the $\mathrm{pH}$ of the colon environment and prevent $\mathrm{pH}$-sensitive bacteria or pathogenic bacteria such as Enterobacteriaceae and Clostridia from healthy colon and improve nutrient absorption [10]. Anaerobic microbiota dominating the colon produce SCFAs along with $\mathrm{CO}_{2}, \mathrm{H}_{2}$ and $2 \mathrm{CH}_{4}$. SCFAs are the results of carbohydrate fermentation which cannot be digested in the upper gastrointestinal and thus fermented in colon. The results of fermentation product in the form of SCFA serving as a source of energy regulators, as well as anti-inflammatory [29].

Probiotics are reported to have a greater effect on malnourished children compared to healthy children living in developing countries [13]. Other studies reported that consumption of probiotics Lactobacillus casei CRL 431 and Lactobacillus reuteri DSM 17938 modestly increase the body weight of undernourished 1-6 years children in Indonesia [14]. Supplementation of probiotic Lactobacillus acidophilus for 6 months for children 2-5 years maybe beneficial with respect in diarrheal morbidity and accelerated growth [15].

This study showed that L. plantarum Dad-13 was able to proliferate in the intestine of children and increased the population of this bacteria. Previous study reported that consumption of probiotics L. plantarum Dad-13 at $10^{9} \mathrm{CFU} /$ gram (the same number as in this study) was able to colonize intestinal wall and suppress colonization of pathogenic bacteria in the intestine [18]. Previous study reported similar finding, in which consumption of probiotics L. plantarum P-8 high doses may significantly increase L. plantarum and Bifidobacterium up to $6 \times 10^{10} \mathrm{CFU}[30]$.

Lactobacillus. plantarum Dad-13 was proven to decrease E. coli in $70 \%$ of healthy Indonesian subjects [18]. The decline of these bacteria could be linked to the ability of L. plantarum Dad-13 in inhibiting the growth of pathogenic bacteria $[17,31]$.

It was also stated that L. plantarum is lactic acid bacteria that common for Indonesian, showing by the high of rate detection in faecal material of younger and elderly in Yogyakarta and Bali [32]. Lactobacillus plantarum is suggested to be suitable as a probiotic for Indonesians.

In this study, an increase in both L. plantarum and Bifidobacterium, and a decrease in some of Enterobacteriacea (E. coli and Klebsiella) cause the increased of SCFA and decrease of the intestinal pH. All these support better conditions of the intestine, so that the absorption of nutrients was better, even though the diet did not appear to be different, the weight of the probiotic group increased significantly.

To conclude, the energy intake of undernourished children in East Lombok, Indonesia did not meet RDA standard (<70\%). Dietary consumption was mainly dominated by carbohydrate (rice, porridge) and protein (fish, seafood). Dietary fibers and vitamins were least consumed.

Consumption of probiotic powder containing L.plantarum Dad-13 with viable cells of $10^{9} \mathrm{CFU} / \mathrm{gram}$ every day for 60 days was able to significantly increase body mass index (BMI) of undernourished children in East Lombok, Indonesia. This increase is linked to the colonization of L. plantarum Dad-13 which is able to maintain the integrity of intestine and enable more optimum nutrient absorption. 
No significant reduction was observed in the number of $B$. fragilis and Prevotella, Escherichia coli, Enterococcus and Streptococcus. However, L. plantarum and Bifidobacterium increased significantly which can be correlated to the reduction of Enterobacteriaceae population. Moreover, consumption of probiotics L. plantarum Dad-13 could improve faecal consistency from type 2 and type 3 to type 4 , which is considered as normal feces. The concentration of short chain fatty acids (acetic, propionic, butyric) increased significantly, while pH decreased significantly.

\section{Abbreviations}

BMI: Body Mass Index; CFU: Colony Forming Unit; DNA: Deoxyribonucleic acid; FID: Flame lonization Detector (FID); RDA: Recommended Dietary Allowance; FNCC: Food and Nutrition Culture Collection; GCP: Good Clinical Practice; PCR: Polymerase Chain Reaction; RNA: Ribonucleic acid; SCFA: Short Chain Fatty Acid; SD: Standard Deviation.

\section{Declarations}

\section{Acknowledgement}

Research teams would like to thank all study participants for their enormous support. In addition, help and support from Elementary Schools of Belanting 3 and 5 and local government who allow the research to be conducted are really appreciated. Finally, this study is financially supported by Ministry of Research, Technology and Higher Education of the Republic of Indonesia.

\section{Author contribution}

ESR, as principal investigator, and TU were responsible for the study design. AM, SS, IE equally carried out most of the field research and laboratory analysis with the supervision of MM. ESR and MM wrote the original draft of manuscript. ESR, TU, FHP and PNH analysed the data and revised the manuscript. MNC acted as the consultant for the study design. MJ supervised the submission of ethical clearance and acted as the consultant from the medical and ethical view.

\section{References}

1. WHO. What is malnutrition? [Internet]. 2016. Available from: https://www.who.int/features/qa/malnutrition/en/

2. UNICEF/WHO/WBG. Levels and trends in child malnutrition 2018. Jt Child Malnutrition Estim 2018 Ed [Internet]. 2018;1-15. Available from: https://www.who.int/nutgrowthdb/2018-jme-brochure.pdf

3. Indonesian Ministry of Health. Riset Kesehatan Dasar 2013. Basic Heal. Res. Jakarta; 2013.

4. Million M, Diallo A, Raoult D. Gut microbiota and malnutrition [Internet]. Microb. Pathog. 2017. p. 127-38. Available from: https://doi.org/10.1016/j.micpath.2016.02.003

5. Conlon MA, Bird AR. The impact of diet and lifestyle on gut microbiota and human health. Nutrients [Internet]. 2015;7:17-44. Available from: https://doi.org/10.3390/nu7010017 
6. De Filippis F, Pellegrini N, Vannini L, Jeffery IB, La Storia A, Laghi L, et al. High-level adherence to a Mediterranean diet beneficially impacts the gut microbiota and associated metabolome. Gut microbiota [Internet]. 2016;65:1812-21. Available from: http://dx.doi.org/10.1136/gutjnl-2015-309957

7. Gevers D, Kugathasan S, Denson LA, Vázquez-Baeza Y, Van Treuren W, Ren B, et al. The treatment-naive microbiome in new-onset Crohn's disease. Cell Host Microbe [Internet]. 2014;15:382-92. Available from: https://doi.org/10.1016/j.chom.2014.02.005

8. Relman DA. Undernutrition-Looking Within for Answers. Sci Bull [Internet]. 2013;339:530-1. Available from: https://doi.org/10.1126/science.1234723

9. FAO/WHO. Guidelines for the Evaluation of Probiotics in Food. 2002.

10. Shiori T, Yahagi K, Nakayama S, Asahari T, Yuki N, Kawakami K, et al. The Effects of a Synbiotic Fermented Milk Beverage Containing Lactobacillus casei Strain Shirota and Transgalactosylated Oligosaccharides on Defecation Frequency, Intestinal Microflora, Organic Acid Concentrations, and Putrefactive Metabolites of Sub-Opti. Biosci microflora [Internet]. 2006;25:137-46. Available from:

https://doi.org/10.12938/bifidus.25.137

11. Roessler A, Forssten SD, Glei M, Ouwehand AC, Jahreis G. The effect of probiotics on faecal microbiota and genotoxic activity of faecal water in patients with atopic dermatitis: A randomized, placebo-controlled study. Clin Nutr [Internet]. 2012;31:22-9. Available from: https://doi.org/10.1016/j.clnu.2011.08.012

12. Bezirtzoglou E, Stavropoulou E. Immunology and probiotic impact of the newborn and young children intestinal microflora. Anaerobe [Internet]. 2011;17:369-74. Available from:

https://doi.org/10.1016/j.anaerobe.2011.03.010

13. Onubi OJ, Poobalan AS, Dineen B, Marais D, McNeill G. Effects of probiotics on child growth: A systematic review. J Heal Popul Nutr [Internet]. 2015;34:1-15. Available from: https://doi.org/10.1186/s41043-0150010-4

14. Agustina R, Bovee-Oudenhoven IMJ, Lukito W, Fahmida U, Rest O van de, Zimmermann MB, et al. Probiotics Lactobacillus reuteri DSM 17938 and Lactobacillus casei CRL 431 Modestly Increase Growth, but Not Iron and Zinc Status, among Indonesian Children Aged 1-6 Years. J Nutr [Internet]. 2013;143:1184-93. Available from: https://doi.org/10.3945/jn.112.166397

15. Saran S, Gopalan S, Krishna TP. Use of fermented foods to combat stunting and failure to thrive. Nutrition [Internet]. 2002;18:393-6. Available from: https://doi.org/10.1016/S0899-9007(01)00790-0

16. Rahayu ES. Lactic Acid Bacteria in Fermented foods of Indonesian Origin. Agritech J Fak Teknol Pertan UGM [Internet]. 2003;23:75-84. Available from: https://doi.org/10.22146/agritech.13515

17. Rahayu ES, Yogeswara A, Mariyatun, Windiarti L, Utami T, Watanabe K. Molecular characteristics of indigenous probiotic strains from Indonesia. Int J Probiotics Prebiotics. 2015;11:109-16.

18. Rahayu ES, Cahyanto M., Windiarti L, Sutriyanto J, Kandarina T, Utami T. Effects of Consumption of Fermented Milk Containing Indigenous Probiotic Lactobacillus Plantarum Dad-13 on the Fecal Microbiota of Healthy Indonesian Volunteers. Int J Probiotics Prebiotics. 2016;11:91-8.

19. Rahayu ES, Rusdan IH, Athennia A, Kamil RZ, Pramesi PC, Marsono Y, et al. Safety Assessment of Indigenous Probiotic Strain Lactobacillus plantarum Dad-13 Isolated from Dadih Using Sprague Dawley Rats as a Model. Am J Pharmacol Toxicol. 2019;14:38-47. 
20. Utami T, Cahyanto MN, Juffrie M, Rahayu ES, Technology A, Mada UG, et al. Recovery of Lactobacillus casei Strain Shirota (LCS) from the Intestine of Healthy Indonesian Volunteers After Intake of Fermented Milk and Its Impact on the Enterobacteriaceae Faecal Microbiota. 2015;10:77-84.

21. Salazar N, Dewulf EM, Neyrinck AM, Bindels LB, Cani PD, Mahillon J, et al. Inulin-type fructans modulate intestinal Bifidobacterium species populations and decrease fecal short-chain fatty acids in obese women. Clin Nutr [Internet]. 2015;34:501-7. Available from: https://doi.org/10.1016/j.clnu.2014.06.001

22. Otuneye A, Ahmed P, Abdulkarim A, Aluko O, Shatima D. Relationship between dietary habits and nutritional status among adolescents in Abuja municipal area council of Nigeria. Niger J Paediatr [Internet]. 2017;44:128-35. Available from: http://dx.doi.org/10.4314/njp.v44i3.1

23. Nakayama J, Watanabe K, Jiang J, Matsuda K, Chao SH, Haryono P, et al. Diversity in gut bacterial community of school-age children in Asia. Sci Rep [Internet]. 2015;5:1-12. Available from: https://doi.org/10.1038/srep08397

24. Ohland C, Macnaughton W. Probiotic bacteria and intestinal epithelial barrier function. Am J Physiol [Internet]. 2010;298:807-19. Available from: https://doi.org/10.1152/ajpgi.00243.2009

25. Monira S, Nakamura S, Gotoh K, Izutsu K, Watanabe H, Alam NH, et al. Gut microbiota of healthy and malnourished children in Bangladesh. Front Microbiol [Internet]. 2011;2:1-7. Available from: https://doi.org/10.3389/fmicb.2011.00228

26. Alou MT, Million M, Traore SI, Mouelhi D, Khelaifia S, Bachar D, et al. Gut bacteria missing in severe acute malnutrition, can we identify potential probiotics by culturomics? Front Microbiol [Internet]. 2017;8:1-17. Available from: https://doi.org/10.3389/fmicb.2017.00899

27. Pekmez CT, Dragsted LO, Brahe LK. Gut microbiota alterations and dietary modulation in childhood malnutrition - The role of short chain fatty acids. Clin Nutr [Internet]. Elsevier Ltd; 2018;38:615-30. Available from: https://doi.org/10.1016/j.clnu.2018.02.014

28. Liu Y, Gibson GR, Walton GE. Impact of high fat diets, prebiotics and probiotics on gut microbiota and immune function, with relevance to elderly populations. Nutr Aging [Internet]. 2016;3:171-92. Available from: https://doi.org/10.3233/nua-150058

29. Egawa Y, Tsugaki M. A bound on the order of a graph when both the graph and its complement are contraction-critically k-connected. Australas J Comb. 2005;32:105-10.

30. Wang L, Zhang J, Guo Z, Kwok L, Ma C, Zhang W, et al. Effect of oral consumption of probiotic Lactobacillus planatarum P-8 on fecal microbiota, SIgA, SCFAs, and TBAs of adults of different ages. Nutrition [Internet]. 2014;30:776-83. Available from: http://dx.doi.org/10.1016/j.nut.2013.11.018

31. Sumaryati, Utami T, Suparmo. The effect of infection of Escherichia coli and addition of Lactobacillus plantarum Dad-13 on infected Wistar mice with Escherichia coli. Agritech J Fak Teknol Pertan UGM [Internet]. 2009;26:165-70. Available from: https://doi.org/10.22146/agritech.9692

32. Rahayu ES, Utami T, Mariyatun M, Hasan PN, Kamil RZ, Setyawan RH, et al. Gut microbiota profile in healthy Indonesians. World J Gastroenterol [Internet]. 2019;25:1478-91. Available from: https://dx.doi.org/10.3748/wjg.v25.i12.1478

33. Matsuda K, Tsuji H, Asahara T, Matsumoto K, Takada T, Nomoto K. Establishment of an analytical system for the human fecal microbiota, based on reverse transcription-quantitative PCR targeting of multicopy 
rRNA molecules. Appl Environ Microbiol [Internet]. 2009;75:1961-9. Available from:

https://doi.org/10.1128/AEM.01843-08

34. Huijsdens XW, Linskens RK, Mak M, Meuwissen SGM, Vandenbroucke-Grauls CMJE, Savelkoul PHM. Quantification of bacteria adherent to gastrointestinal mucosa by real-time PCR. J Clin Microbiol [Internet]. 2002;40:4423-7. Available from: https://doi.org/10.1128/JCM.40.12.4423-4427.2002

35. Lee DY, Lauder H, Cruwys H, Falletta P, Beaudette LA. Development and application of an oligonucleotide microarray and real-time quantitative PCR for detection of wastewater bacterial pathogens. Sci Total Environ [Internet]. 2008;398:203-11. Available from: https://doi.org/10.1016/j.scitotenv.2008.03.004

36. Hermann-Bank ML, Skovgaard K, Stockmarr A, Larsen N, Mølbak L. The Gut Microbiotassay: A highthroughput qPCR approach combinable with next generation sequencing to study gut microbial diversity. BMC Genomics [Internet]. 2013;14:1-14. Available from: https://doi.org/10.1186/1471-2164-14-788

\section{Figures}

$\mathrm{n}=40$ subjects

(20 consuming probiotic powder, 20 consuming placebo powder)

\section{Duration}

Consumption period 60 days

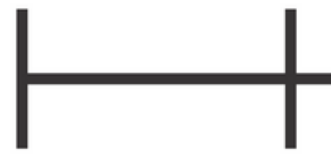

Day 0

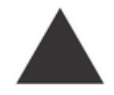

Screening
Day 1

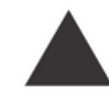

Faecal Collection 1
Faecal Collection 2

\section{Figure 1}

Schematic diagram of research design 


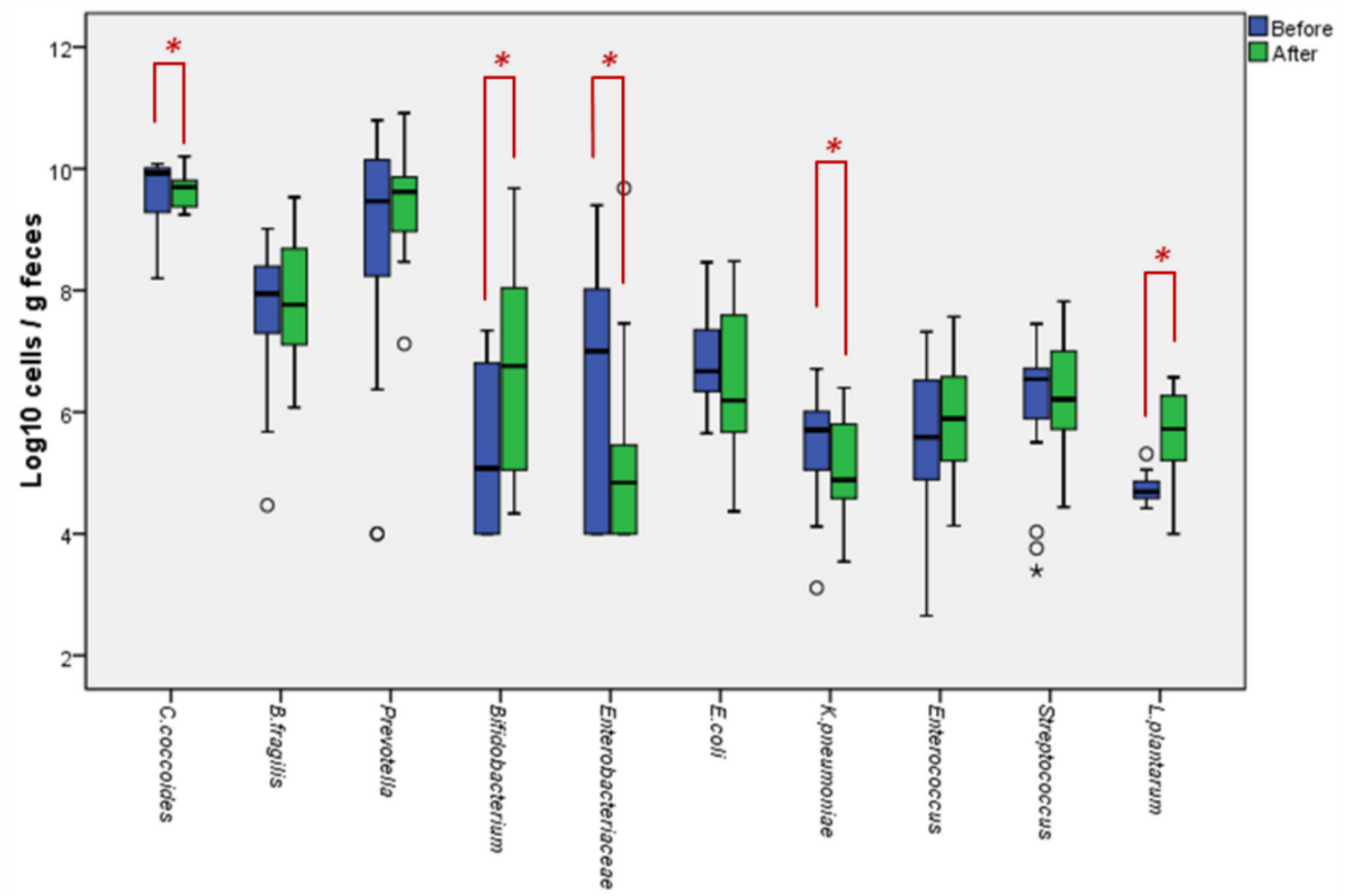

Microbiota

Figure 2

Comparison of gut microbiota composition in undernourished children before and after consumption of powder of probiotic L. plantarum Dad-13. 